\title{
Penicillin sensitivities of gonoccocci, in 1977-80 from a peripheral health district, and their clinical correlation
}

\author{
M. RAHMAN \\ M.B. B.S., D.Bact., M.R.C.Path. \\ Department of Microbiology, King's Mill Hospital, Sutton-in-Ashfield, Notts NG 17
}

\begin{abstract}
Summary
Penicillin sensitivities of gonococci isolated from a peripheral health district were observed during 1977-80 by determining the minimum inhibitory concentrations (MIC) of penicillin. During the same period, outcome of penicillin treatment in patients with gonorrhoea was also observed and recorded. Penicillin resistance, as defined, was found in $19.3 \%$ strains in these years, but there were year-to-year variations. None of the strains was a penicillinase producer. Association of higher MICs of penicillin with therapeutic failures was not observed in this study until the MICs were greater than $1.0 \mathrm{mg} / \mathrm{l}$. The findings are discussed together with reviews from other published works.
\end{abstract}

\section{Introduction}

Penicillinase-producing gonococci (PPNG) together with their association with failure of penicillin treatment were first reported from Britain in 1976 (Philips, 1976; Percival et al., 1976). Since then, there have been many such reports. High level of penicillin resistance in non-penicillinase producing strains (non-PPNG) has also been reported recently (Seth and Johnston, 1980), although their clinical correlation was not clearly demonstrated. Most of these reports came from big cities or areas close to them. It is also known that antibiotic sensitivities of organisms vary from place to place and year to year (Rahman, 1978; Seth, Kolator and Wilkinson, 1979). The following study was undertaken to assess the penicillin sensitivities of gonococci from this peripheral health district consisting of small towns and villages and to see if there were any clinical correlations with the laboratory-observed'sensitivities.

\section{Materials and methods}

Since September 1977, minimum inhibitory concentrations (MIC) of penicillin against all strains of gonococci isolated from this district have been determined, using antibiotic-incorporated agar and an inoculum of $10^{4}$ colony-forming units approximately. Details of the media and techniques were as described by Seth et al. (1979). All results were recorded and, for the purpose of this study, results up to the end of 1980 were taken. Penicillin resistance was arbitrarily defined as MIC $0.25 \mathrm{mg} / \mathrm{l}$ for this study. Tests were always repeated and results confirmed when high MICs were noted $(\geqslant 0.25$ $\mathrm{mg} / \mathrm{l})$. All such strains were also tested for penicillinase production as done by Percival et al. (1976).

Clinical correlationship was judged in a doubleblind way in that MICs were not known to the clinician treating the patients and the outcome of treatment or nature of treatment were not known to the microbiologist until at least 3 weeks after the completion of treatment. Standard treatment of gonorrhoea in absence of complications (such as signs of extragenital or pelvic involvement or abscess) was a single i.m. injection of $2 \mathrm{Mu}$. of procaine penicillin $\mathrm{G}$ with $1 \mathrm{~g}$ of probenecid orally. The treatment was extended up to 5 days with a similar daily dose of both drugs in complicated cases or when one-dose treatment failed. For the purpose of this study, penicillin 'success' was recorded for a patient who remained free of signs and symptoms and free of culturable gonococci one week after the completion of treatment. Where penicillin failure was observed, a careful history from each case confirming that no sexual activities occurred during the treatment and follow-up period was also recorded to exclude the possibility of reinfection. Those who could not be followed-up or had other antibiotics (either because of penicillin allergy or presence of other infections) were excluded from this part of the study.

\section{Results}

There were 62 penicillin-resistant strains out of 321 strains tested $(19.3 \%$ resistant $)$ in these years. None was found to be a penicillinase producer. Details of the MICs found in 1977-80 are given in Table 1. This would show that although there was no significant change in the most frequently observed MICs $(0.015-0.03 \mathrm{mg} / \mathrm{l})$ over these years, the proportion of resistant strains had increased after 1977. 
TABLE 1. Minimum inhibitory concentration (MIC) of penicillin against gonococci isolated in 1977-80

\begin{tabular}{|c|c|c|c|c|c|c|c|c|c|c|c|}
\hline \multirow[b]{2}{*}{ Year } & \multirow{2}{*}{$\begin{array}{l}\text { No. } \\
\text { tested }\end{array}$} & \multicolumn{9}{|c|}{ MIC in $\mathrm{mg} / \mathrm{l}$ against no. of strains ( $\%)$} & \multirow{2}{*}{$\begin{array}{l}\text { No. of resistant* } \\
\text { strains }(\%)\end{array}$} \\
\hline & & 0.015 & 0.03 & 0.06 & $0 \cdot 12$ & $0 \cdot 25$ & $0 \cdot 5$ & $1 \cdot 0$ & $2 \cdot 0$ & $4 \cdot 0$ & \\
\hline $\begin{array}{l}1977 \\
\text { (last } 4 \text { months) }\end{array}$ & 29 & $\begin{array}{c}22 \\
(75 \cdot 8)\end{array}$ & $\begin{array}{c}3 \\
(10 \cdot 3)\end{array}$ & $\begin{array}{c}3 \\
(10 \cdot 3)\end{array}$ & 0 & 0 & 0 & $\begin{array}{c}1 \\
(3 \cdot 4)\end{array}$ & 0 & 0 & $\begin{array}{c}1 \\
(3 \cdot 4)\end{array}$ \\
\hline 1978 & 88 & $\begin{array}{c}25 \\
(28 \cdot 4)\end{array}$ & $\begin{array}{c}19 \\
(21 \cdot 5)\end{array}$ & $\begin{array}{c}13 \\
(14 \cdot 7)\end{array}$ & $\begin{array}{c}11 \\
(12 \cdot 5)\end{array}$ & $\begin{array}{c}6 \\
(6 \cdot 8)\end{array}$ & $\begin{array}{c}7 \\
(7 \cdot 9)\end{array}$ & $\begin{array}{c}5 \\
(5 \cdot 6)\end{array}$ & $\begin{array}{c}2 \\
(2 \cdot 2)\end{array}$ & 0 & $\begin{array}{c}20 \\
(22 \cdot 7)\end{array}$ \\
\hline 1979 & 94 & $\begin{array}{c}22 \\
(23 \cdot 4)\end{array}$ & $\begin{array}{c}24 \\
(25 \cdot 5)\end{array}$ & $\begin{array}{c}17 \\
(18 \cdot 0)\end{array}$ & $\begin{array}{c}9 \\
(9 \cdot 5)\end{array}$ & $\begin{array}{c}5 \\
(5 \cdot 3)\end{array}$ & $\begin{array}{c}6 \\
(6 \cdot 3)\end{array}$ & $\begin{array}{c}5 \\
(5 \cdot 3)\end{array}$ & $\begin{array}{c}4 \\
(4 \cdot 2)\end{array}$ & $\begin{array}{c}2 \\
(2 \cdot 1)\end{array}$ & $\begin{array}{c}22 \\
(23 \cdot 4)\end{array}$ \\
\hline 1980 & 110 & $\begin{array}{c}38 \\
(34 \cdot 5)\end{array}$ & $\begin{array}{c}33 \\
(30 \cdot 0)\end{array}$ & $\begin{array}{c}6 \\
(5 \cdot 4)\end{array}$ & $\begin{array}{c}14 \\
(12 \cdot 7)\end{array}$ & $\begin{array}{c}6 \\
(5 \cdot 4)\end{array}$ & $\begin{array}{c}5 \\
(4 \cdot 5)\end{array}$ & $\begin{array}{c}5 \\
(4 \cdot 5)\end{array}$ & $\begin{array}{c}2 \\
(1 \cdot 8)\end{array}$ & $\begin{array}{c}1 \\
(0 \cdot 9)\end{array}$ & $\begin{array}{c}19 \\
(17 \cdot 2)\end{array}$ \\
\hline
\end{tabular}

It could also be calculated from Table 1 that more than $86 \%$ strains of 1977 were inhibited by $\leqslant 0.03$ $\mathrm{mg} / \mathrm{l}$; whereas between $0.25 \mathrm{mg} / \mathrm{l}$ and $0.5 \mathrm{mg} / \mathrm{l}$ would be required to inhibit a similar proportion of the organisms in the following years.

There was $100 \%$ success with penicillin treatment in patients with sensitive strains (200 patients). There were 46 patients with resistant strains who could be followed-up. Details of the outcome of treatment in these patients are included in Table 2.

TABLE 2. Outcome of treatment in relation to the method of treatment and penicillin minimum inhibitory concentration (MIC)

\begin{tabular}{lccc}
\hline $\begin{array}{c}\text { MIC } \\
(\mathrm{mg} / \mathrm{l})\end{array}$ & $\begin{array}{c}\text { Treatment } \\
\text { method }\end{array}$ & $\begin{array}{c}\text { No. receiving } \\
\text { the treatment }\end{array}$ & $\begin{array}{c}\text { No. of success } \\
(\%)\end{array}$ \\
\hline \multirow{3}{*}{0.25} & SD & 14 & $14(100)$ \\
& 5DC & 1 & $1(100)$ \\
& SDF & 0 & \\
0.5 & SD & 13 & $13(100)$ \\
& 5DC & 2 & $2(100)$ \\
& 5DF & 0 & \\
1.0 & SD & 9 & $9(100)$ \\
& SDC & 1 & $1(100)$ \\
& 5DF & 0 & \\
2.0 & SD & 4 & $1(25)$ \\
& 5DC & 2 & 2 \\
\hline
\end{tabular}

SD, single dose; 5DC, 5-day course because of complications; SDF, 5-day course because of failure after single dose.

This would show that penicillin treatment was $100 \%$ successful when penicillin MIC was $\leqslant 1.0$ $\mathrm{mg} / \mathrm{l}$, irrespective of being given in single dose or 5 -day course (40 patients). But when the MIC was $2 \mathrm{mg} / \mathrm{l}$, there was clinical success in only one out of 4 treated with a single dose of penicillin. These 3 failed cases were re-treated with a 5-day course of penicillin which was successful in 2 cases. The third $\%$ case which failed again was given a single injection $\forall$ of $2 \mathrm{~g}$ of kanamycin which was successful (provedo by 3 subsequent examinations and cultures). In $2^{-}$ other patients with similar strains (penicillin MIC: ${ }_{7}$

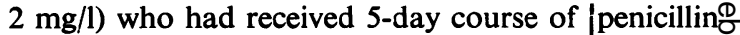
from the beginning because of complications, the treatment was successful.

\section{Discussion}

The study covered 321 organisms and 246 ! followed-up patients over a period of more thक्ष巾응 3 years. Figures for 1977 were from the last 4 months of the year only, whereas those from the following years were from the full calendar year. Thus, in $\%$

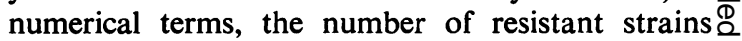
found in 1977 could not be compared with those in $\overrightarrow{\overrightarrow{0}}$ the following years. However, it would seem from 3 the percentage of resistant strains in individual $\bar{\partial}$ years that the proportion of resistant strains hado gone up after 1977 (Table 1). It was also observed that more than $86 \%$ of strains would have been 3 . inhibited by $\leqslant 0.03 \mathrm{mg} / \mathrm{l}$ of penicillin in $1977 ; \dot{0}$ whereas, between $0.25 \mathrm{mg} / \mathrm{l}$ and $0.5 \mathrm{mg} / \mathrm{l}$ would have been required to inhibit the same proportion of $\delta$ organisms in the following years. It was thus $₹$ probable that there was a genuine increase of 0 penicillin resistance after 1977. There was no $>$ penicillinase-producing strain. Gradual increase of penicillin resistance in non-PPNG strains after $1976 \stackrel{\mathrm{N}}{\mathrm{N}}$ or during the 1970s has been reported from various $ᄋ$ countries including the U.K. (Nayyar, Michel and N Stolz, 1980; Shtibel, 1980; Seth and Johnston, 1980). N In the present study, a fall in the percentage of 0 resistant strains was noted in 1980 . Whether it was $a_{0}$ genuine downwards trend or a chance variation $\frac{}{\Phi}$ can only be observed after a further study. It $\stackrel{9}{\rightarrow}$ can at least be said, at this stage, that there was no 0 appreciable increase of penicillin resistance during $\bar{O}$ 
$1978-80$ in this locality. This was contrary to the experience from another region of the U.K. (Dowsett, 1980), where resistance was seen in $2.5 \%, 10.7 \%$ and $37.3 \%$ in 1978,1979 and 1980 respectively. A few of these strains from that region were penicillinase producers, which have not been found so far in this district. However, a problem in comparing the rate of resistance from several reports arises from the fact that there were either different or no clearcut definitions of 'resistance' (Meheus et al., 1976; Seth et al., 1979; Nayyar et al., 1980).

Some correlations of higher MICs of penicillin with therapeutic failures have been observed before (Holmes et al., 1973). But the present study has demonstrated that penicillin treatment would be clinically effective in infections with 'penicillinresistant' non-PPNG strains when the MICs of penicillin were $\leqslant 1.0 \mathrm{mg} / \mathrm{l}$. This would not be entirely surprising in the light of recent observations on the pharmacokinetic determinants of the cure of gonorrhoea with penicillin (Jaffe et al., 1979). After injections of 2.4-4.8 Mu. of procaine penicillin $G$, serum concentrations of penicillin were expected to be $10-34 \mathrm{mg} / \mathrm{l}$, and higher concentrations would be maintained for several hours if probenecid were also given. Jaffe et al. concluded from their study that the cure of gonococcal urethritis was most likely to occur when serum penicillin concentrations were 3-4 times the MIC of the infecting strain and remained at these levels for $7-10 \mathrm{hr}$. These conditions would be met if the MIC against the infecting strain was $1.0 \mathrm{mg} / \mathrm{l}$. However, with the MIC higher than this, the serum concentration of penicillin might have fallen shorter than the required 4 times of the MIC, resulting in therapeutic failures in certain cases. In the present study, penicillin failure was initially seen in 3 out of 4 cases treated with a single dose of penicillin, where MIC against the infecting strains was $2 \mathrm{mg} / \mathrm{l}$. When these 3 failed cases were retreated with a 5-day course, failure was still seen in one patient who was successfully treated with another antibiotic.

For this study, gonococci were called 'penicillinresistant' when the MIC of penicillin was $\geqslant 0.25 \mathrm{mg} / \mathrm{l}$. Other studies have even taken MIC of $0.125 \mathrm{mg} / \mathrm{l}$ to mean penicillin-resistance (Seth et al., 1979). As infections with such strains would be clinically and bacteriologically cured with the currently used high dose of penicillin, it is arguable whether one should call such strains 'penicillin-resistant' unless there is evidence of penicillinase production. There is a need for a more clinically significant definition of penicillin-resistance for gonococci. One final observation which could be made from this study is that penicillin in the currently used high doses is still highly effective in treating gonorrhoea, as has been observed by others (Seth et al., 1979). It was particularly reassuring for this district that there were no PPNG strains.

\section{Acknowledgments}

I thank Dr R. Statham, consultant veneriologist of this health district, for his personal help and co-operation in this study. I thank the staff of this laboratory for their assistance, and Miss K. Pugh for her secretarial assistance.

\section{References}

Dowsert, E.G. (1980) Penicillin-resistant gonococci. Lancet, ii, 202.

Holmes, K.K., Karney, W.W., Harnisch, J.P., Wiesner, P.J., Turck, M. \& Pedersen, A.H.B. (1973) Single dose aqueous procaine penicillin $G$ therapy for gonorrhoea: use of probenecid and cause of treatment failure. Journal of Infectious Diseases, 127, 455.

Jaffe, H.W., Schroeter, A.L., Reynolds, G.H., Zaidi, A.A., Martin, J.E. \& Thayer, J.D. (1979) Pharmacokinetic determinants of penicillin cure of gonococcal urethritis. Antimicrobial Agents and Chemotherapy, 15, 587.

Meheus, A., Piot, P., Pattyn, S., Vandyck, E. \& VandenBERG, D. (1976) Activity in vitro of ten antimicrobial agents against Neisseria gonorrhoeae. A study of correlation between the sensitivities. British Journal of Venereal Diseases, 52, 329.

Nayyar, K.C., Michel, M.F. \& Stolz, E. (1980) Antibiotic sensitivities of gonococci isolated in Rotterdam and results of treatment with cefuroxime. British Journal of Venereal Diseases, 56, 249.

Percival, A., Corkill, J.E., Arya, O.P., Rowlands, J., Alergant, C.D., Rees, E. \& ANNels, E.H. (1976) Penicillinase-producing gonococci in Liverpool. Lancet, ii, 1379.

Phillips, I. (1976) Beta-lactamase producing penicillinresistant gonococcus. Lancet, ii, 656.

Rahman, M. (1978) Antibiotic resistance in Streptococcus pneumoniae and Haemophilus influenzae. British Medical Journal, 2, 569.

Seth, A.D., Kolator, B. \& Wilkinson, A.E. (1979) Sensitivity of Neisseria gonorrhoeae to antibiotics in London (1976-78). British Journal of Venereal Diseases, 55, 325.

Seth, A.D. \& Johnston, N.A. (1980) Penicillin-resistant gonococci. Lancet, ii, 531.

ShTIBEL, R. (1980) Non-beta-lactamase-producing Neisseria gonorrhoeae highly resistant to penicillin. Lancet, ii, 39. 